\title{
MONITORING OF ECOSYSTEMS IN AN OIL-EXTRACTING AREA
}

\author{
Ljudmila Kapelkina ${ }^{I}$ \\ Ljubov Malyshkina ${ }^{I}$ \\ Ljudmila Bakinal \\ Alexander Korolev ${ }^{2}$ \\ Tatjana Koroleva ${ }^{3}$ \\ Ljudmila Usova ${ }^{4}$ \\ Sergei Bakkal \\ ${ }^{I}$ Scientific Research Center of Ecological Safety RAS, Russia \\ ${ }^{2}$ State Scientific Institute of River and Lake Fish Industry, Russia \\ 3 Komarov Botanical Institute RAS, Russia \\ ${ }^{4}$ State Hydrological Institute, Russia \\ ${ }^{5}$ Zoological Institute, Russia
}

\begin{abstract}
Complex monitoring has been carried out by five institutes of St.Petersburg Scientific Center in on of the oil-fields, located in boggy landscape in the Western Siberia. The aim of investigations is to estimate the conditions of land and water ecosystems around drilling wells and in oil-extraction zone. Field work was performed in the surroundings of boring grounds at different technological stages: 1) sand road pads construction, 2) drilling of wells, 3) wells under exploitation (oil extraction stage). During the field work the laboratory investigations and chemical analyses of soil samples have been made. The state of soil and vegetation cover, soil microbial community, entomofauna, hydrobionts, ground vertebrates and birds has been studied. Soil microorganisms, plants, animals, hydrobionts have been used as bioindicators.

Local changes of the components of environment caused by natural and technogenic factors were found. Typical changes in ecosystems caused by impact of different technogenic disturbances (oil spills, salt waters, technical oils, drilling muds, flooding by ground waters) were determined. The results of our investigations showed that the level of changes of ecosystems caused by technogenic impact was determined by three factors: the direction and intensity of impact, its duration and ecological resistance of ecosystem on a whole. Along with uniformity of technogenic impact in the different types of ecosystems, different deviations in their condition have been observed. In spite of rather pronounced deviations in the condition of different components of environment the determined changes in the most cases have the reversible character.
\end{abstract}

\section{KEYWORDS}

Oil extraction; West Siberia; Monitoring; Ecosystems 


\section{INTRODUCTION}

Intensive technogenic effect upon natural complexes of the West Siberia associated with the development of oil fields changes natural complexes (Table 1). To minimize the negative effect of drilling and exploitation of oil fields along with strict control of technological processes and transportation, the organization of the efficient control of the ecosystems state and prognoses for its changes. The variety of cummulative effects, connected with oil field development in different environmental conditions stipulates diverse and often non-adequate reactions of ecosystems to technogenic impact [1]. It explains the necessity of prognosis of the behaviour of main pollutants (oil composition, concentration of accompanying salts, type and toxicity of reagents). The purpose of monitoring in the oil-extracting and transporting regions is to watch over the state and the changes of ecosystems, to forecast the development of possible negative processes and to prevent the dangerous for the components of the environment situations [2]. The results of monitoring can be assessed by feedback efficiency, possibility of preventing dangerous situations and processes. The results obtained by monitoring must be considered when locating industrial objects (roads, drilling grounds etc.) and carrying out construction, drilling and extraction works, transporting hydrocarbons.

\section{STUDY AREA AND MATERIALS}

Complex monitoring of ecosystems was performed at the Tyansky oil field (West Siberia) situated in a boggy landscape at the border between north taiga and middle taiga. Monitoring was conducted during 3 years by 5 institutes of St-Petersburg Scientific Center. The work aimed at assessment of the state of aquatic and terrestrial ecosystems in the impact zone of oil well drilling. Field work was conducted around drilling grounds at various technological stages: 1 - sandy road pads and drilling puds; 2 - wildcat drilling; 3 - functioning wells (stage of oil extraction). Field studies were complemented by laboratory investigation and chemical analysis of samples. The state of soil and vegetation cover was investigated, together with soil micro-biota, insect fauna, terrestrial vertebrates and birds, water organisms (phyto- and zooplankton, zoobenthos and ichthyofauna of surrounding water bodies), and hydrological regime of the area was assessed. Soil microorganisms, plants, animals, hydrobionts were used as bioindicators. Biological monitoring of terrestrial and aquatic ecosystems was preceded by investigation of composition and properties of drilling waste (drilled rock containing drilling fluids). 
Table 1. The impact of industrial objects and linear constructions on the environments.

\begin{tabular}{|c|c|c|c|c|c|}
\hline \multirow{2}{*}{$\begin{array}{l}\text { Industrial } \\
\text { constructions }\end{array}$} & \multicolumn{4}{|c|}{ Impacts on different components of the environment } & \multirow{2}{*}{$\begin{array}{l}\text { Changes of environment } \\
\text { which are not caused by } \\
\text { technogenic influence } \\
1 . \text { Natural fluctuations of } \\
\text { ecosystems }\end{array}$} \\
\hline & Lands & Hydrology & Atmosphere & Biological resources & \\
\hline \multirow[t]{2}{*}{ Drilling wells } & $\begin{array}{l}\text { Withdrawn of lands } \\
\text { from traditional land- } \\
\text { use, construction of } \\
\text { pads, contamination of } \\
\text { surfaces with drilling } \\
\text { fluids, oil, communal } \\
\text { waste, metal waste }\end{array}$ & $\begin{array}{l}\text { Contamination of surface } \\
\text { and underground waters is } \\
\text { possible in some cases }\end{array}$ & $\begin{array}{l}\text { Burning } \\
\text { torches }\end{array}$ & $\begin{array}{l}\text { Damage of vegetation and } \\
\text { mezofauna in the sites of drilling. } \\
\text { Changes in chemical composition } \\
\text { of lakes and other natural water } \\
\text { reservoirs. Damage and destruction } \\
\text { of vegetation cover }\end{array}$ & \multirow{3}{*}{$\begin{array}{l}\text { 2. Hazard to vegetation } \\
\text { caused by pests, } \\
\text { degradation of reindeer } \\
\text { pastures due to } \\
\text { overgrazing. } \\
\text { 3. Fires of non- } \\
\text { technogenic origin. } \\
\text { 4. Disturbance of } \\
\text { vegetation and soil cover } \\
\text { not connected with } \\
\text { industrial activities. }\end{array}$} \\
\hline & $\begin{array}{l}\text { Withdrawn of lands, } \\
\text { construction of pads. } \\
\text { Impoundments, } \\
\text { thermokarst. }\end{array}$ & $\begin{array}{l}\text { Disturbance of surface } \\
\text { and underground run off }\end{array}$ & $\begin{array}{l}\text { Contamina- } \\
\text { tion by } \\
\text { exhausts. } \\
\text { Dust from } \\
\text { roadsides. }\end{array}$ & $\begin{array}{l}\text { Disturbance of migration routes of } \\
\text { reindeer and wild animals, total } \\
\text { damage to biocoenoses under the } \\
\text { road, noise }\end{array}$ & \\
\hline Pipelines & $\begin{array}{l}\text { Withdrawn of lands, } \\
\text { constructing of pads, } \\
\text { compaction of ground } \\
\text { under the construction. } \\
\text { Contamination of lands } \\
\text { during accidental spills. }\end{array}$ & $\begin{array}{l}\text { Flooding and forming of } \\
\text { bog-like conditions are } \\
\text { possible on hill slopes and } \\
\text { in depressions. } \\
\text { Disturbance of surface and } \\
\text { underground run off. } \\
\text { Contamination of surface } \\
\text { and underground waters } \\
\text { during accidents }\end{array}$ & $\begin{array}{l}\text { Impact is } \\
\text { not essential }\end{array}$ & $\begin{array}{l}\text { The same as above. Also damage to } \\
\text { biological resources by } \\
\text { contamination with oil products. }\end{array}$ & \\
\hline
\end{tabular}


Environmental feedback to technogenic impact is mainly determined by three factors direction and level of technogenic impact, its duration and ecosystem resistance. Combination of these three factors stipulates ecosystem feedback to the technogenic impact. In connection with that, we want to underline the fact that in boggy ecosystems containing oligotrophic habitats [3] and very low salt composition, moderate change in $\mathrm{pH}$ and slightly increasing salt concentration may act as fertilizing and neutralize an increased $\mathrm{pH}$ [4]. Oligotrophic habitats can change to mesotrophic [5]. In other words, technogenic alkaline and weakly-salty arrays can positively impact certain localized habitats (boggy over-humid ecosystems). In boggy ecosystems with a high groundwater table one must avoid oil spills, because they threaten with oil uptake through brook net into fishery reservoirs. When groundwater table is sufficiently low, peat is a good absorbent and can absorb oil contamination [see also 6].

Initial stage of development of oil fields is the construction of roads (road pads) and drilling pads. Natural sandy grounds are used for it. At this stage of work, main effect is associated with exclusion of a part of bog landscape from production process, due to pouring sand over the site, changing hydrological regime of sites adjoining well grounds or roads. Water is pulled out, weak flooding is seen. Later owing to water or erosion, the area under roads or grounds increases. On this stage, mechanic effect impacts soil and plants cover. Hydrophilous vegetation expands, i.e. sphagnum mosses spreads over dwarf-shrubs, the height of latter relatively decreases.

The next stage is transporting the equipment, technique; construction of drilling pads. All these works take place on sand pads and the main negative effect is the noise stressing birds and animals.

Technogenic floods can occur at the stage of drilling wells and preparing them for exploitation. Drilling fluids and chemical reagents can spread into the neighbouring environments. Composition of drilling fluids vary depending on geological technical conditions and drilling depth. As a rule they are water solutions of certain clay types, emulsions with different chemical admixtures.

Local changes of environment are determined by natural or anthropogenic factors. Typical changes of ecosystems under technogenic disturbances (oil spills, mineralized water, technical oil, drilling slime and flooding caused by higher groundwater) are defined. Besides, comparative identification of environmental changes was conducted (i.e. in plants cover, under technogenic above-mentioned effects, and under a rare natural phenomenon - a hurricane with hail which stayed on soil surface 12 hours.

\section{RESULTS}

The results of research showed that the level of ecosystem change under anthropogenic impact is determined mainly by three factors: direction, intensity of technogenic impact, duration of the impact and environmental stability of ecosystem on the whole. Even when technogenic impact is uniform, in various types of ecosystems, it can display various deviations of their status. Despite the pronounced deviations in the state of various components of environment, those changes in most cases are reversible. Three-year long monitoring of terrestrial and aquatic ecosystems (their hydrological regime, soils, soil microflora, fish fauna of water bodies) reveals most representative, informative indices characterizing the state of biogeocenoses and most important changes observed in ecosystems under the impact of drilling works and oil extraction. 


\subsection{Assessment of state of hydrological regime of area}

Three-year-long monitoring reveals that for the evaluation of the state of hydrological regime of an area it is necessary to monitor: a detailed field hydrological survey of bog landscapes around drilling grounds; mapping bog types and hydrodynamic nets of running lines of bog waters at sites directly adjoining drilling grounds.

Field work allowed to reveal the post-impact effects of drilling activities (pollution or flooding) in separate small sites, adjoining drilling grounds. It is revealed that the most considerable effect on bog ecosystems in oil extraction zone is caused by the construction of pads, roads etc and the associated changes of hydrological regime.

\subsection{Assessment of state of soil cover and soil microbionts}

Soil cover of the studied area is dominated by peat oligotrophic soils (peat upper bog soils) of various thickness. Changes of soil cover are determined mainly by deflation of sand owing to water and air erosion. These changes are registered as appearance of sand cover of different thickness, decreasing as the distance from grounds increase. They are no revealed differences in morphological structure of soils around cluster grounds where drilling was performed according to old or new technology.

Soils of the studied area are characterized by the low number of microorganisms (actynomycets are completely absent), and by low activity of microbiological processes, which is typical for damp peat-bog soils of north-taiga zone.

Microbial community of the studied soils is relatively stable and tolerant to man impact (oil extraction) and does not seriously change. Saprophytic bacteria decrease in number, number of bacilli increase in soils adjoining drilling grounds. There are no differences in the number, group composition and specific features of soil micro-biota functioning around cluster wells' grounds, where drilling is conducted according to various technologies.

\subsection{Assessment of plant cover state}

State of plant cover was monitored during research on 9 geobotanic profiles founded near 8 drilling grounds, in order to comprise all vegetation types. In the studied area there are bogs of two types - zonal olygotrophic ridge-pool bogs in a ridge-lakelet stage; and smaller ridgemoor mesotrophic bogs [7]. Owing to their specific features, these bogs are highly tolerant to external effects. Monitoring showed that there are no considerable changes in vegetation of bogs surrounding wells' clusters. On the whole, state of vegetation in the studied sites was satisfactory, though local negative impact of chemical liquids upon the vegetation was registered almost around all drilling grounds. Near all drilling grounds berry dwarf-shrubs had fruits. Most conifers showed good annual accretion and massive ripening of cones, especially in Siberian pine. Most considerable damages of vegetation cover was observed in the following cases: near one drilling ground (N20) as a result of mineral water spill in 1999, by well development (disturbance area 2-2.5 ha); as a result of insect damage (damage of cloudberry leaves by caterpillars in 2000) and after a hurricane with hail (in 2000 vegetation cover was damaged on tens of hectares near ground, N44). When there are no accidents, no negative impact upon vegetation is made by stocking up drilling waste in barns on sand platforms.

Negative changes in state of vegetation on separate local and relatively small sites caused by pollution with technological liquids owing to breaking technical rules, are the following: 
sphagnum mosses get suppressed and disappear; lichens and dwarf-shrubs do the same; pine withers; species with greater capacity for vegetative propagation spread (rhizomatous sedges, cotton sedges). Vegetation still has bog type, but acquires more eutrophic character and species diversity decreases. Exotic ruderal plants (evidence of destruction of bog ecosystem) were not found on the damaged sites of bogs.

In our opinion, revealed changes in vegetation cover must be complemented by sampling soils and chemical analysis of samples in order to precise plant response to different kinds of pollution.

\subsection{Assessment of state of hydrobionts}

Ecosystems of 7 lakes of the Tyansky oil field were included in complex monitoring of 5 main components, with the following results:

Phytoplankton. Studying the biota of 7 lakes of the Tyansky oil field revealed no negative effect of discharge from wells' clusters upon the development of phytopankton. No decrease in number or biomass of phytoplankton was registered in any lake. No regular differences were revealed in dynamics of quantitative indices of lake phytoplankton depending on drilling technology.

Zooplankton. There was no distinct impact of well clusters exploitation upon zooplankton, except for some aspects. Zooplankton did not change species composition in three monitoring years. Dominants changed within years (crustaceans increased its share owing to decreasing role of some rotifer species). It was explained by natural reasons and inter-annual fluctuation of rotifers number. Zooplankton number varied from minimal -4.72 thousand inds $/ \mathrm{m}^{3}$ (in Grusha lake) to maximal 252 thousand inds $/ \mathrm{m}^{3}$ (in Gagara lake). Biomass of zooplankton also varied between lakes. Its minimum was registered in (Grusha lake $0.024 \mathrm{~g} / \mathrm{m}^{3}$ ) and maximum in Yanteklor lake $\left(4.08 \mathrm{~g} / \mathrm{m}^{3}\right)$.

Zoobenthos. Species composition of zoobenthos is middle-abundant, chironomids and small mollusks prevail. Altogether 47 species and forms of bottom organisms were discovered (larvae of chironomids, mollusks, oligochets, leeches, heleids, caddis-flies, mites, beetles, dayflies, alder and snake flies, etc. (nematodes and water mites are defined to genus).

On the whole, composition and abundance of water organisms in studied lakes and their dynamics during the study period showed no negative impact of drilling products or drilling technologies. Quantitative indices of zoobenthos in most lakes did not change in most lakes during three monitoring years.

Ichthyofauna. It was registered in large running lakes (3 of 7 studied). Species composition of fish fauna was poor but relatively abundant for the region. Absence of fish in some lakes is explained by natural reasons: seasonal migrations of fish, isolation of water bodies, specific traits of hydrological and hydrochemical regime in wintertime (e.g. freezing of a water body till the bottom). During investigation period, natural fluctuation of number of id and roach in water bodies. Population structure of ruff, perch and pike did not change. On the whole, good growing rate of carp fish, relative stability in population structure of perchand pike point to the absence of negative impact of drilling products. 


\subsection{Assessing the status of terrestrial vertebrates and birds}

The fauna of investigated ecosystems of the Tyansky oil field is typical for north taiga boggy landscape of the Western Siberia [8]. The main technogenic factor affecting animals and birds around drilling grounds is noise. Our investigations did not reveal any sufficient technogenic impact on reproductive indices of terrestrial vertebrates, and revealed no deviations from normal development in experimental and control sites. Registered reproductive losses of birds in investigated sites during monitoring period were caused by natural reasons. The structure of terrestrial vertebrates' communities did not show considerable changes during three reproductive seasons. Apparently nowadays in investigated areas of land and water of the Tyansky oil field there is no real danger of extinction of any north-taiga species, as a result of industrial activity.

\section{CONCLUSIONS}

The results of three-year monitoring testify to satisfactory state of ecosystems around drilling ground clusters. There are no considerable differences between drilling according to various technologies. Revealed damages of various components of biogeocenoses were mainly local and reversible in most cases. Main factor providing environmental safety around drilling grounds' clusters is sticking to technological regulations, nature-conservation standards and rules during construction, drilling and exploiting oil wells.

\section{REFERENCES}

[1] Kapelkina, L.P., 1993. Ecological aspects of optimisation of man-made landscapes. Nauka, Sp Petersburg, 191 p. (in Russian).

[2] Bulatov, A.I., Makarenko, P.P., Shemetov, V.Yu., 1997. Protection of the environment in oil-gas industry. Nedra, Moscow, 482 p. (in Russian).

[3] Romanova, E.A., 1967. Some morphologic characters of oligotrophic boggy landscapes in the West Siberian Lowland as a base for their typology and regional delimitation. In: Nature of bogs and methods of its investigation. Nauka, Leningrad, p p. $63-67$ ( in Russian).

[4] Potapova, T.M., 1986. The influence of meliorative activities on hydrochemical regime and dynamics of concentration of mineral and organic substances in peat-boggy waters. Works of the all-union research institute of the peat industry. Is.56. Leningrad, pp. 5464 (in Russian).

[5] Novikov, S.M., 1984. The change of plant living condition on the bogs of West Siberia under industrial development. In: The protection on plants of northern regions. V.2, pp.23-27 (in Russian).

[6] Potapova, T.M., Novikov, S.M., Valushko, I.I., 2000. Regularities of accumulation of oil contamination in the active layer of bogs and their ecological role as natural filters. Vestnik of St.Petersburg State University. Ser.7, is.1, 12-18.

[7] Ivanov, K.E., Novikov S.M. 1976. Mires of West Siberia, structure and hydrologic regime. Nauka, Leningrad, $448 \mathrm{p}$.

[8] Anonymous. 1998. Biological diversity of animals of Siberia. Tomsk, Russia. 